\title{
Proinsulin Synthesis in Islets of Langerhans from Spiny Mice (Acomys Cahirinus). Comparison with Rats and Mice*
}

\author{
P. A. Trueheart**, A. Maldonato***, D. Kaelin, A. E. Renold and G. W. G. Sharp \\ Institut de Biochimie Clinique, Université de Genève, Genève, Switzerland
}

Summary. Proinsulin synthesis in response to different concentrations of glucose has been studied in islets of Langerhans of acomys, rat and mouse. The response to increased glucose was small in acomys when compared with rat or mouse. The time course of the effect of glucose on proinsulin synthesis was also studied in sequential $15 \mathrm{~min}$ periods up to $60 \mathrm{~min}$. With $5.5 \mathrm{mM}$ glucose the rate of ${ }^{3} \mathrm{H}$-leucine incorporation for acomys islets was greater over the periods $15-30,30-45$ and $45-60 \mathrm{~min}$ after the addition of glucose to the islets than at $0-15 \mathrm{~min}$. By contrast rat islets exhibited a greater glucose-induced stimulation between $15-30$ and $30-45 \mathrm{~min}$ relative to the $0-15$ min period and a further increase of the incorporation rate between 45 and $60 \mathrm{~min}$. With $27.5 \mathrm{mM}$ glucose acceleration of incorporation relative to the first 15 min period occurred at 15-30 min; it was then stable up to $60 \mathrm{~min}$ for islets both from acomys and from rat. Incorporation into total protein was much greater in acomys than in rat or mouse: thus in $2.75 \mathrm{mM}$ glucose, acomys islets incorporated 5 and 19 times more ${ }^{3} \mathrm{H}$-leucine into total protein than did islets from rat or mouse respectively. In $27.5 \mathrm{mM}$ glucose the incorporation into total protein of the islets from acomys was 4 and 13 times greater. Islet content of insulin was similar for all three species. No significant changes in ATP content were observed in response to changes in glucose concentration from 2.75 to $27.5 \mathrm{mM}$. The results demonstrate a decreased responsiveness of proinsulin synthesis to glucose in acomys and are discussed in terms of the known decreased sensitivity of insulin release in this animal.

\footnotetext{
* This work was supported by Grant No. 3106073 from the Fonds National Suisse pour la Recherche Scientifique

** Current address: Department of Medicine, Washington University School of Medicine, St. Louis, Missouri, U.S. A.

*** Current address: Cattedra di Endocrinologia, II Clinica Medico, Universita di Roma, Rome, Italy
}

Key words: Spiny mouse (Acomys cahirinus), islets of Langerhans, proinsulin synthesis, ${ }^{3} \mathrm{H}$-leucine incorporation, glucose.

Acomys cahirinus maintained in the Geneva colony exhibit hyperplasia of the islets of Langerhans [1-3] and a retarded as well as reduced rate of insulin release in response to glucose challenge by comparison with rats or mice [4-7]. These differences in the response profile to glucose have been detected in vivo, after either intraperitoneal [4-5] or intravenous [6] glucose injection, and in vitro, using isolated islets [7-9]. While acomys islets respond slowly to glucose, the total release of insulin over a two hour period may be comparable to that of rats, at least at higher glucose concentrations [7-9], suggesting predominantly early decreased sensitivity to glucose. Indeed, when the early and late release phases were compared in some detail [7-9], it was confirmed that the early phase (1-10 min) of insulin release from acomys islets exhibited both decreased sensitivity to glucose and a decreased release capacity. By contrast, the late phase (20-30 $\mathrm{min}$ ) of insulin release from acomys islets exhibited only decreased sensitivity to glucose. As these time/secretion characteristics resemble in some respects observations reported in latent diabetes as well as maturity onset diabetes in man [10-12] acomys has attracted attention as a possible "model" of potential usefulness. Because of this and because the insensitivity to glucose might be carried over to the control of insulin biosynthesis we have undertaken a study of ${ }^{3} \mathrm{H}$-leucine incorporation into proinsulin and other proteins of islets of Langerhans of Acomys cahirinus. 


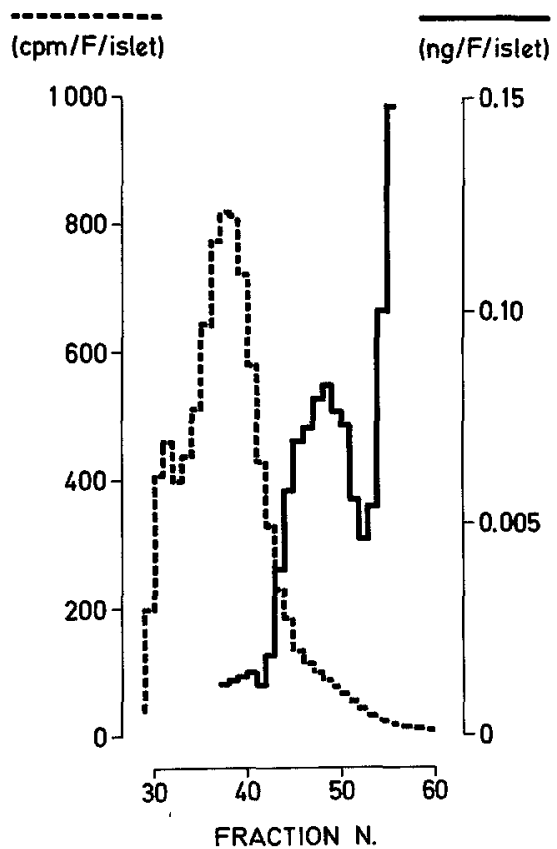

Fig. 1. Elution profiles of ${ }^{3} \mathrm{H}$-leucine incorporation (CPM/fraction/ islet) and immunoreactivity (ng immunoreactive insulin/fraction/ islet) in the supernatant of sonicated acomys islets. The islets were incubated with ${ }^{3} \mathrm{H}$-leucine and $27.5 \mathrm{mM}$ glucose for $30 \mathrm{~min}$ prior to processing
P.A. Trueheart et al.: Proinsulin Synthesis in Islets of Langerhans

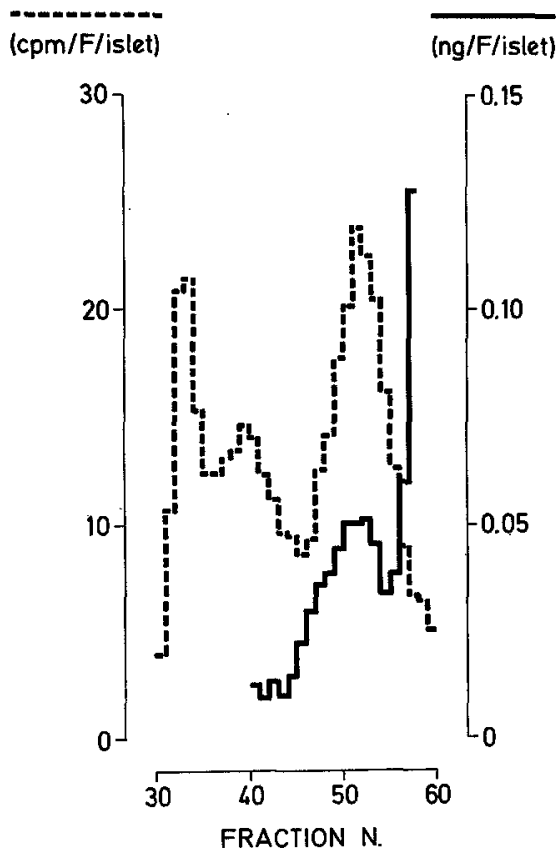

Fig. 2. Elution profiles of ${ }^{3} \mathrm{H}$-leucine incorporation (CPM/fraction/ islet) and immunoreactivity (ng immunoreactive insulin/fraction/ islet) in the supernatant of sonicated acomy islets after precipitation of large proteins with $80 \%$ ethanol. The islets were incubated with ${ }^{3} \mathrm{H}$-leucine and $27.5 \mathrm{mM}$ glucose for $30 \mathrm{~min}$ prior to processing

\section{Materials and Methods}

Experiments were performed on islets of Langerhans from three animal species: Wistar-derived rats, Swiss albino mice, and spiny mice (Acomys cahirinus), all bred in this laboratory. The rats weighed $150-200 \mathrm{~g}$ at 6-12 weeks of age, the 8-14 week old mice $25-30 \mathrm{~g}$, and the acomys aged 8-12 weeks weighed $25-35 \mathrm{~g}$. All were given water and chow ad libitum. Islets of Langerhans were isolated by collagenase digestion of minced pancreas according to Lacy and Kostianovsky [13]. After isolation, the islets were washed twice in Hank's solution $\left(\mathrm{NaCl} 137 \mathrm{mM}, \mathrm{KCl} 5.4 \mathrm{mM}, \mathrm{MgSO}_{4}\right.$ $0.81 \mathrm{mM}, \mathrm{Na}_{2} \mathrm{HPO}_{4} 0.33 \mathrm{mM}, \mathrm{KH}_{2} \mathrm{PO}_{4} 0.44 \mathrm{mM}$, $\mathrm{CaCl}_{2} 1.26 \mathrm{mM}, \mathrm{NaHCO}_{3}$ to adjust $\mathrm{pH}$ to 7.4 when gassed with $95 \% \mathrm{O}_{2}, 5 \% \mathrm{CO}_{2}$ ) containing $5 \mathrm{mM}$ glucose and distributed into siliconized incubation flasks. 120-180 islets were used for any one flask. Incubations were performed in $1 \mathrm{ml}$ Krebs-Ringer bicarbonate (KRB) buffer containing $0.5 \%$ bovine serum albumin and a mixture of essential amino acids (Eagle Hela) but no leucine. Equilibration was with continuous flow of $95 \% \mathrm{O}_{2}, 5 \% \mathrm{CO}_{2}, \mathrm{pH}$ being maintained at or near 7.4. Agitation at 120 cycles per min was achieved in a Dubnoff metabolic shaking incubator at $37^{\circ} \mathrm{C}$.

Incorporation of ${ }^{3} \mathrm{H}$-leucine into proinsulin and total protein was measured after incubation in the presence of different concentrations of glucose and for different periods of time. During the 15 or $30 \mathrm{~min}$ periods of exposure to leucine $100 \mu \mathrm{Ci}$ of $\mathrm{L}-4,5-{ }^{3} \mathrm{H}-$ leucine $(53 \mathrm{Ci} / \mathrm{mmol}$, Radiochemical Centre, Amersham, U.K.) was added to the incubation medium. The individual protocols are described in the section on results.

At the end of this incubation the islets were washed with ice-cold KRB buffer, placed in ice-cold Hanks solution and three batches of $30-50$ islets counted into three tubes. To each of the latter $2 \mathrm{ml}$ cold glycine buffer ( $\mathrm{pH} 8.8$ ) plus $0.25 \%$ human serum albumin (HSA) was added. The islets were sonicated with a Branson sonifier and stored at $-20^{\circ} \mathrm{C}$. In preliminary experiments, aliquots of the sonicates were centrifuged at $4000 \mathrm{~g}$ for $20 \mathrm{~min}$, in preparation for column chromatography. In all later experiments, however, aliquots of the sonicates were first mixed with cold absolute ethanol to give a final concentration of $80 \% \mathrm{v} / \mathrm{v}$, then centrifuged at $4000 \mathrm{~g}$ for $20 \mathrm{~min}$. The supernatants were removed and dried in vacuo. The residues were taken up in glycine-HSA buffer and aliquots chromatographed on $1 \times 120 \mathrm{~cm}$ columns of Sephadex G-50 fine (Pharmacia, Uppsala, Sweden). Elution was performed with glycine HSA buffer; $1 \mathrm{ml}$ fractions were collected and aliquots mixed with In- 
stagel scintillation liquid prior to measurement of radioactivity in a Beckman liquid scintillation spectrometer.

Aliquots of the column effluent samples were also assayed for insulin immunoreactivity by conventional radioimmunoassay using the charcoal separation method of Herbert et al. [14]. Standard rat insulin, kindly prepared by Dr. J. Schlichtkrull (Novo Research Institute, Copenhagen, Denmark) was used for the assay of rat and also of mouse samples; standard human insulin (Dr. Schlichtkrull) was used for the assay of acomys samples as previously described [6]. ${ }^{125} \mathrm{I}$ porcine insulin was prepared by the method of Hunter and Greenwood [15]. Antiporcine insulin serum raised in guinea pigs (AIS lot 563) was kindly donated by Dr. P. Wright (Indiana University, Indianapolis).

The chromatographic technique used has been shown to separate proinsulin from insulin satisfactorily. Incorporation of ${ }^{3} \mathrm{H}$-leucine into proinsulin was estimated by summing the radioactivity in the fractions corresponding to the peak of immunoreactivity. Peaks of radioactivity and immunoreactivity were coincident. At the end of $30 \mathrm{~min}$ there was no appreciable conversion of proinsulin to insulin, since there was no peak of radioactivity corresponding to the peak of insulin immunoreactivity.

For estimation of incorporation of ${ }^{3} \mathrm{H}$-leucine into total proteins, aliquots of the original sonicates were precipitated with $10 \%$ trichloroacetic acid (TCA) and freed from non-covalently bound ${ }^{3} \mathrm{H}$-leucine by alternately dissolving in $0.5 \mathrm{ml} 0.125 \mathrm{~N} \mathrm{NaOH}$ and reprecipitating with TCA, this being repeated three times.

For measurement of ATP, the luciferase assay described by Strehler and Totter [16] was used, with the modifications introduced by Wettermark et al. [17] and Ashcroft et al. [18]. At the end of the $90 \mathrm{~min}$ incubation, $0.03 \mathrm{ml}$ of ice-cold $20 \%$ perchloric acid (PCA) was added to the tubes containing $0.6 \mathrm{ml} \mathrm{KRB}$ and the islets homogenized by sonication for $45 \mathrm{sec}$. The samples were then centrifuged and $0.1 \mathrm{ml}$ of the supernatant was added to $5 \mathrm{ml}$ of the firefly enzymatic solution. ATP standards were made up in $2 / 3 \mathrm{KRB}$ and $1 / 3$ PCA, after eliminating the precipitate. The standard curve was linear up to 500 pmoles $/ 100 \mu \mathrm{l}$.

\section{Results}

Separation of proinsulin: Figure 1 illustrates the radioactivity and immunoreactivity profiles obtained for the effluent from a G-50 fine Sephadex chromatography column after preliminary experiments with acomys islets incubated for $30 \mathrm{~min}$ with ${ }^{3} \mathrm{H}$-leucine
Table 1. Proinsulin content of extracts of acomys, rat and mouse islets expressed as the percentage of total insulin immunoreactivity present both before and after purification of the extracts by the addition of cold $80 \%$ ethanol. The data are from separate unpaired experiments and no significant differences was found

\begin{tabular}{llll}
\hline Species & $\begin{array}{l}\text { Acomys } \\
(\mathrm{n}=48)\end{array}$ & $\begin{array}{l}\text { Rats } \\
(\mathrm{n}=21)\end{array}$ & $\begin{array}{l}\text { Mouse } \\
(\mathrm{n}=48)\end{array}$ \\
\hline Before purification & $2.56 \pm 0.06$ & $3.68 \pm 0.44$ & $4.16 \pm 0.11$ \\
After purification & $2.55 \pm 0.08$ & $3.26 \pm 0.13$ & $4.32 \pm 0.16$ \\
\hline
\end{tabular}

Table 2. ${ }^{3} \mathrm{H}$-leucine incorporation into proinsulin of acomys, rat and mouse islets expressed as dpm in proinsulin per islet \pm SEM. Islets were preincubated in the presence of different concentrations of glucose for 15 or $60 \mathrm{~min}$ before the addition of ${ }^{3} \mathrm{H}$-leucine for a 30 min incorporation period. $10 \mathrm{mM}$ pyruvate was added to the low glucose $(2.75$ and $4.125 \mathrm{mM})$ media. It should be noted that the experiments performed with 15 and $60 \mathrm{~min}$ preincubations are not paired. The experiments were carried out at different times of the year and thus may not be directly compared

\begin{tabular}{|c|c|c|c|c|c|}
\hline \multicolumn{6}{|c|}{ Glucose concentration (mM) } \\
\hline & 2.75 & 4.125 & 5.5 & 8.25 & 27.5 \\
\hline \multicolumn{6}{|c|}{15 min preincubation } \\
\hline \multicolumn{6}{|c|}{ Acomys } \\
\hline $\begin{array}{l}n=6 \\
\text { Rat }\end{array}$ & $14.8 \pm 1.0$ & $19.8 \pm 1.3$ & $23.2 \pm 2.4$ & & $34.1 \pm 7.4$ \\
\hline $\begin{array}{l}\mathrm{n}=6 \\
\text { Mouse }\end{array}$ & $15.0 \pm 2.4$ & & $61.3 \pm 4.0$ & & $106.6 \pm 6.5$ \\
\hline $\mathrm{n}=6$ & $7.7 \pm 1.3$ & & $22.1 \doteqdot 4.6$ & $35.1 \pm 0.8$ & $77.0 \pm 8.7$ \\
\hline \multicolumn{6}{|c|}{60 min preincubation } \\
\hline $\begin{array}{l}\text { Acomys } \\
\mathrm{n}=6 \\
\text { Rat }\end{array}$ & $22.8 \pm 3.6$ & $29.9 \pm 3.1$ & $36.8 \pm 3.5$ & & $42.7 \pm 2.8$ \\
\hline $\begin{array}{l}n=6 \\
\text { Mouse }\end{array}$ & $12.7 \pm 1.8$ & & $62.4 \pm 9.3$ & & $107.7 \pm 13.9$ \\
\hline$n=6$ & $13.6 \pm 0.5$ & & $50.0 \pm 3.1$ & $92.7 \pm 9.1$ & $111.5 \pm 5.8$ \\
\hline
\end{tabular}

and $27.5 \mathrm{mM}$ glucose. In this instance the islet sonicate was centrifuged and an aliquot applied to the column without further extraction. A very large peak of radioactivity associated with relatively large newly synthesized protein is seen, which tails off into the area of proinsulin as defined by insulin immunoreactivity. No peak of radioactivity seemed clearly associated with proinsulin. It was assumed that the radioactivity incorporated into proinsulin was obscured by the radioactivity of the many other, and larger, proteins. However, when the sonicates were treated with $80 \%$ ethanol prior to centrifugation and column chromatography many of the contaminating proteins and large peptides containing ${ }^{3} \mathrm{H}$-leucine were precipitated. The effluent radioactivity and immunoreactivity profiles obtained, again from acomys islets, are shown in Figure 2. The separation of proinsulin is sufficient to allow for estimation of the corresponding radioactivity. Similarly, easily identifiable peaks of proinsulin and insulin were obtained from 


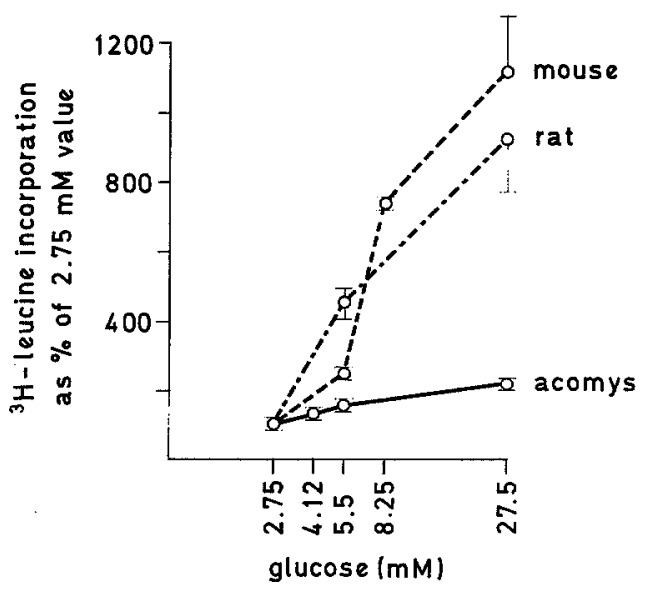

Fig. 3. ${ }^{3} \mathrm{H}$-leucine incorporation into proinsulin in islets of acomys, rat and mouse. Islets werc preincubated with different concentrations of glucose for $15 \mathrm{~min}$ before the addition of ${ }^{3} \mathrm{H}$-leucine. Incorporation was stopped after a further $30 \mathrm{~min}$. The results arc expressed in terms of the percentage increase in radioactivity incorporated relative to the incorporation in the presence of $2.75 \mathrm{mM}$ glucose. Vertical bars represent \pm SEM

mouse and rat islets using this technique. A possible drawback of the method was that ethanol precipitation was reproducibly associated with the loss of $53 \pm$ $1.2 \%(\mathrm{SEM}, \mathrm{n}=83)$ of the total insulin immunoreactivity accounted for by proinsulin and insulin. Accordingly all values were corrected for loss by dividing by 0.53 , in order to allow for comparison with the results of others. That the ethanol precipitation step does not interfere with our interpretation of the raw data can be seen from the results in Table 1 in which proinsulin is expressed as the percentage of total insulin immunoreactivity: precipitation with ethanol did not alter the proinsulin to insulin ratio.

\section{Effect of 15 min Preincubation with Glucose on ${ }^{3} \mathrm{H}$-Leucine Incorporation into Proinsulin}

The effects of different concentrations of glucose on ${ }^{3} \mathrm{H}$-leucine incorporation into proinsulin are shown in Table 2 and Figures 3 and 4 for two different durations of exposure to glucose. In the first series of experiments, the islets were preincubated for $15 \mathrm{~min}$ with the different concentrations of glucose. ${ }^{3} \mathrm{H}$-leucine was then added, glucose concentration remaining unchanged, and the incubation continued for a further $30 \mathrm{~min}$. In the second series, the islets were preincubated with the same glucose concentrations but for 60 min before ${ }^{3} \mathrm{H}$-leucine was added and the incubation again continued for a further $30 \mathrm{~min}$. It can be seen from Table 2 and Figure 3 that after 15 min of preincubation at glucose concentrations of 5.5 and 27.5

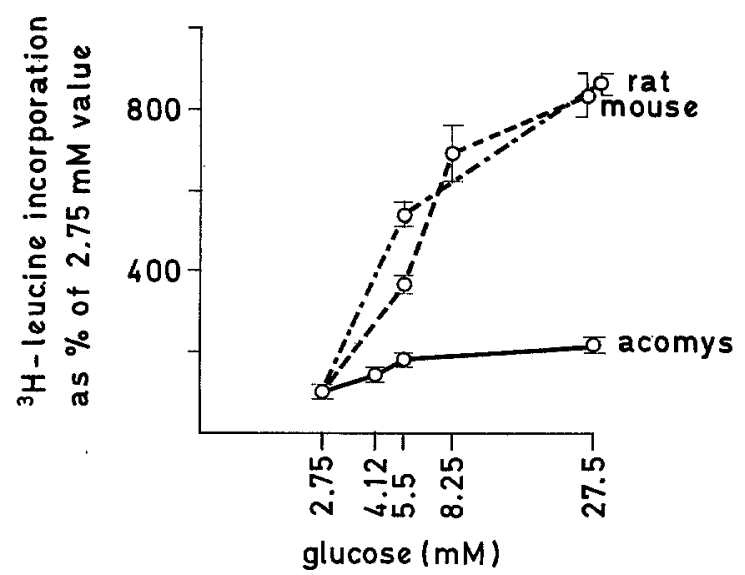

Fig. 4. ${ }^{3} \mathrm{H}$-leucine incorporation into proinsulin in islets of acomys, rat and mouse. Islets were preincubated with different concentrations of glucose for $60 \mathrm{~min}$ before the addition of ${ }^{3} \mathrm{H}$-leucine. Incorporation was stopped after a further $30 \mathrm{~min}$. The results are cxpressed in terms of the percentage increase in radioactivity incorporated relative to the incorporation in the presence of $2.75 \mathrm{mM}$ glucose. Vertical bars represent \pm SEM

$\mathrm{mM},{ }^{3} \mathrm{H}$-leucine incorporation was increased relative to the incorporation attained when $2.75 \mathrm{mM}$ glucose was used during preincubation and incubation. For both mouse and rat the incorporation of ${ }^{3} \mathrm{H}$-leucine into proinsulin was significantly greater after preincubation with glucose $5.5 \mathrm{mM}$ than $2.75 \mathrm{mM}(\mathrm{p}<$ 0.001 ), and also for glucose $27.5 \mathrm{mM}$ relative to 5.5 $\mathrm{mM}(\mathrm{p}<0.001)$. The stimulation achieved by $5.5 \mathrm{mM}$ relative to $2.75 \mathrm{mM}$ glucose was more pronounced in the rat than the mouse.

Turning to acomys, incorporation of ${ }^{3} \mathrm{H}$-leucine into proinsulin was not grossly different from that in the other 2 species at the lowest concentration of glucose $(2.75 \mathrm{mM})$. However, whereas incorporation was stimulated by increasing glucose concentration, the relative change was much less than that seen in rat or mouse islets (Fig. 3). For example, with $27.5 \mathrm{mM}$ glucose, rat and mouse islets responded with a 9 and 11-fold increase respectively over incorporation into proinsulin at $2.75 \mathrm{mM}$ glucose, while the corresponding increase for acomys islets was only 2 -fold. In a single experiment, increasing the glucose concentration further to $55.5 \mathrm{mM}$ had no additional effect.

\section{Effect of $60 \mathrm{~min}$ Preincubation with Glucose on ${ }^{3}$ H-Leucine Incorporation into Proinsulin}

In these experiments preincubation was for $60 \mathrm{~min}$ and four glucose concentrations were compared with the lowest one, $2.75 \mathrm{mM}$. Incorporation of ${ }^{3} \mathrm{H}$-leucine into proinsulin was markedly stimulated by 5.5 and 


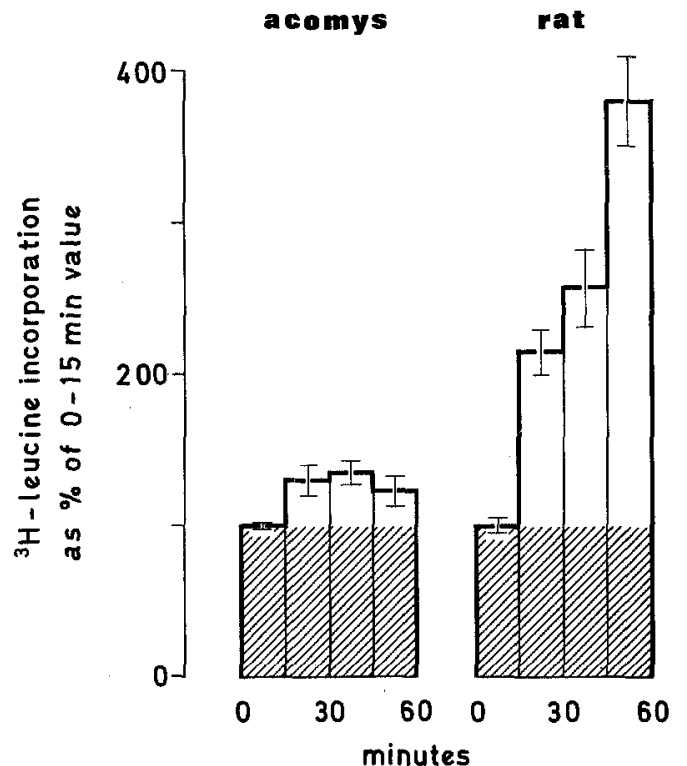

Fig. 5. ${ }^{3} \mathrm{H}$-leucine incorporation into proinsulin in islets of acomys and rat after different periods of exposure to $5.5 \mathrm{mM}$ glucose. Islets were incubated in the glucose media and ${ }^{3} \mathrm{H}$-leucine added at 0,15 30 and $45 \mathrm{~min}$. All incubations were stopped $15 \mathrm{~min}$ after the addition of ${ }^{3} \mathrm{H}$-leucine. Results are expressed in terms of the percentage increase in radioactivity incorporated relative to the incorporation during the period $0-15 \mathrm{~min}$. Vertical bars represent \pm SEM

$27.5 \mathrm{mM}$ glucose in rat and mouse islets. At $27.5 \mathrm{mM}$ glucose the increase was 8 fold relative to the rate at $2.75 \mathrm{mM}$ (Fig. 4). By contrast the glucose-induced increase of incorporation into proinsulin of acomys islets was much smaller, stimulation with $27.5 \mathrm{mM}$ glucose relative to $2.75 \mathrm{mM}$ barely reaching a factor of 2 .

\section{Time Course of Adaptation to Glucose of ${ }^{3} H$-Leucine Incorporation into Proinsulin}

With the demonstration of increased ${ }^{3} \mathrm{H}$-leucine incorporation into proinsulin in response to increased glucose in the medium, and of species differences in the response to the duration of the preincubation, additional information on the time course of the likely adaptive increased biosynthesis involved was sought. Accordingly, the incorporation of ${ }^{3} \mathrm{H}$-leucine was measured over each of the four consecutive $15 \mathrm{~min}$ periods after the addition of glucose. Two series of experiments were performed, one using $5.5 \mathrm{mM}$ glucose and the other $27.5 \mathrm{mM}$ glucose. ${ }^{3} \mathrm{H}$-leucine was added to the medium for one of the periods: $0-15$, $15-30,30-45$ and 45-60 min. All incubations were stopped $15 \mathrm{~min}$ after the addition of ${ }^{3} \mathrm{H}$-leucine. Comparison was between rat and acomys islets. Results with $5.5 \mathrm{mM}$ glucose appear in Table 3 and Figure 5.

For rat islets, ${ }^{3} \mathrm{H}$-leucine incorporation into proin-

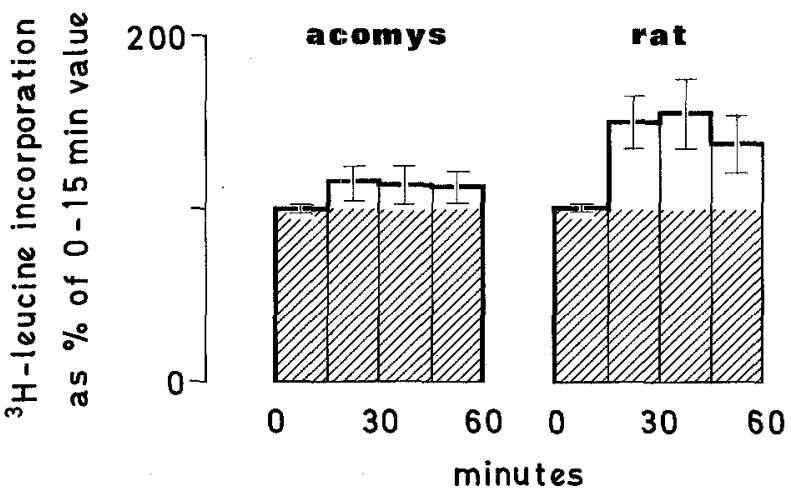

Fig. 6. ${ }^{3} \mathrm{H}$-leucine incorporation into proinsulin in islets of acomys and rat after different periods of exposure to $27.5 \mathrm{mM}$ glucose. Islets were incubated in the glucose media and ${ }^{3} \mathrm{H}$-leucine added at $0,15,30$ and $45 \mathrm{~min}$. All incubations were stopped $15 \mathrm{~min}$ after the addition of ${ }^{3} \mathrm{H}$-leucine. Results are expressed in terms of the percentage increase in radioactivity incorporated relative to the incorporation during the period $0-15$ min. Vertical bars represent \pm SEM

sulin per 15 min was greater at $15-30$ min and $30-45$ min than at $0-15 \min (p<0.001)$. The rate increased again at $45-60 \mathrm{~min}(\mathrm{p}<0.01)$ so that two apparent rate changes occurred in response to the addition of glucose, one at approximately $15 \mathrm{~min}$ and the other at approximately $45 \mathrm{~min}$. For acomys islets the results were quite different. The rate of ${ }^{3} \mathrm{H}$-leucine incorporation into proinsulin icreased slightly at $15-30 \mathrm{~min}$ relative to $0-15 \mathrm{~min}(\mathrm{p}<0.01)$ but remained constant thereafter and through $60 \mathrm{~min}$.

The results of experiments using $27.5 \mathrm{mM}$ glucose on rat and acomys islets are shown in Figure 6 and Table 3 and differ from the results obtained with 5.5 $\mathrm{mM}$ glucose. In rat islets the rate of ${ }^{3} \mathrm{H}$-leucine incorporation increased at $15-30 \mathrm{~min}$ relative to the $0-15$ min time period $(\mathrm{p}<0.02)$. However, no further change in rate occurred beyond $30 \mathrm{~min}$ and up to 60 min. Acomys islets showed no significant increase from the rate at $0-15 \mathrm{~min}$. In one experiment the incubation was continued for 3 hours with a $30 \mathrm{~min}$ ${ }^{3} \mathrm{H}$-leucine incorporation and still no subsequent increase in rate was detected.

\section{Effect of 2.75 and $27.5 \mathrm{mM}$ Glucose on Non-Hormonal Protein Synthesis}

Total protein synthesis in the presence of 2.75 and $27.5 \mathrm{mM}$ glucose was also measured in the islets from the three animals. When the $\mathrm{dpm}$ in proinsulin are subtracted from the total protein dpm the incorporation of ${ }^{3} \mathrm{H}$-leucine into non-hormonal protein is obtained. This is expressed in Table 4. No significant increase in incorporation was observed with the change in glucose concentration. The absolute number of counts incorporated into total proteins at 
Table 3. ${ }^{3} \mathrm{H}$-leucine incorporation into proinsulin of islets of acomys and rat after different periods of exposure to $5.5 \mathrm{mM}$ and $27.5 \mathrm{mM}$ glucose. Islets were incubated in the glucose media and ${ }^{3} \mathrm{H}$-leucine added at $0,15,30$ and $45 \mathrm{~min}$. All incubations were stopped $15 \mathrm{~min}$ after the addition of ${ }^{3} \mathrm{H}$-leucine. Results are expressed as dpm/islet $\pm \mathrm{SEM}$. The experiments performed with 5.5 and $27.5 \mathrm{mM}$ glucose were not paired

\begin{tabular}{|c|c|c|c|c|}
\hline \multicolumn{5}{|c|}{ Time Period (min) } \\
\hline & $0-15$ & $15-30$ & $30-45$ & $45-60$ \\
\hline \multicolumn{5}{|c|}{$5.5 \mathrm{mM}$ glucose } \\
\hline $\mathrm{n}=6$ & $25.6 \pm 3.5$ & $34.0 \pm 5.7$ & $35.6 \pm 3.3$ & $30.4 \pm 3.1$ \\
\hline $\mathrm{n}=6$ & $26.7 \pm 1.3$ & $57.6 \pm 5.2$ & $67.7 \pm 5.1$ & $99.9 \pm 4.6$ \\
\hline \multicolumn{5}{|c|}{$27.5 \mathrm{mM}$ glucose } \\
\hline $\begin{array}{l}\text { Acomys } \\
\mathrm{n}=9\end{array}$ & $38.9 \pm 2.5$ & $44.5 \pm 2.7$ & $43.6 \pm 2.8$ & $42.0 \pm 2.4$ \\
\hline $\mathrm{n}=9$ & $93.8 \pm 7.8$ & $136.7 \pm 11.4$ & $147.4 \pm 16.0$ & $121.5 \pm 10.7$ \\
\hline
\end{tabular}

Table 4. ${ }^{3} \mathrm{H}$-leucine incorporation into protein (proinsulin dpm subtracted) and into proinsulin (expressed as the percentage of the counts incorporated into total protein) in islets of acomys, rat and mouse. Islets were incubated for $15 \mathrm{~min}$ in the presence of $2.75 \mathrm{mM}$ and $27.5 \mathrm{mM}$ glucose then $30 \mathrm{~min}$ with ${ }^{3} \mathrm{H}$-leucine and the same glucose concentrations

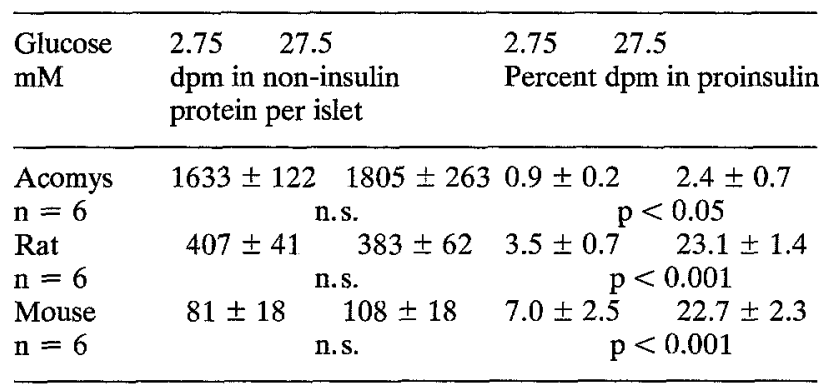

Table 5. ATP content (expressed as pmol/islet \pm SEM) of islets of acomys and rat. Islets were incubated for $90 \mathrm{~min}$ in the presence of $0,2.75,5.5$ and $27.5 \mathrm{mM}$ glucose prior to assay. $10 \mathrm{mM}$ pyruvate was present in the incubations with $0-2.75 \mathrm{mM}$ glucose

\begin{tabular}{llclc}
\hline Glucose $\mathrm{mM}$ & 0 & 2.75 & 5.5 & 27.5 \\
Pyruvate $\mathrm{mM}$ & 10 & 10.0 & 0 & 0 \\
Acomys & & & & \\
$\mathrm{n}=14$ & $9.38 \pm 0.79$ & $9.36 \pm 0.65$ & $9.60 \pm 0.76$ & $10.39 \pm 0.73$ \\
$\begin{array}{l}\text { Rat } \\
\mathrm{n}=9\end{array}$ & $6.85 \pm 0.56$ & $6.98 \pm 0.66$ & $8.24 \pm 0.69$ & $8.58 \pm 0.35$ \\
\hline
\end{tabular}

$2.75 \mathrm{mM}$ glucose by acomys islets was approximately 5 and 19 fold greater than was the case for rat or mouse islets respectively. Accordingly, when incorporation of radioactivity into proinsulin was expressed as the percentage of counts in total protein the propor- tion for acomys was much less than for rat or mouse. The islet content of insulin was for acomys, $23.9 \pm 1.5$, $\mathrm{n}=9$; for mouse $28.7 \pm 2.7, \mathrm{n}=7$; and for rat $28.3 \pm$ $1.4, \mathrm{n}=7$, all expressed as $\mathrm{ng} /$ islet and assayed as described.

\section{Islet Content of ATP}

Islet content of ATP was measured so as to assess their metabolic state in the presence of different concentrations of glucose. As shown in Table 5, acomys islets exhibited a slight but non-significant increase in ATP content as the glucose concentration in the medium was increased from 2.75 to $27.5 \mathrm{mM}$ glucose. A small but non-significant increase of ATP content at 5.5 and $27.5 \mathrm{mM}$ relative to $2.75 \mathrm{mM}$ glucose was also seen in islets of rat, the increases being $18 \%$ and $23 \%$ respectively.

\section{Discussion}

When considering the incorporation of ${ }^{3} \mathrm{H}$-leucine into proinsulin in islets of Langerhans from different species of animals, it is clear that difficulties of interpretation must arise. For instance, the amount of ${ }^{3} \mathrm{H}$-leucine incorporated will not reflect the absolute amount of leucine incorporated nor even the relative amounts between species, because of variation in the size of the endogenous pool of leucine, with consequent variation in the specific activity of intracellular ${ }^{3} \mathrm{H}$-leucine. Thus comparison of such incorporation data on different animals must be made on the basis of relative changes occurring in response to different conditions. Furthermore, even when this is adhered to, differences noted between species must be interpreted cautiously: what is 'normal' for one species may not be normal for another. With these restrictions in mind, studies have been performed on proinsulin synthesis in islets of Langerhans from Acomys cahirinus, the spiny mouse, in which insulin release is markedly insensitive to glucose, when compared with other rodents such as rats or mice [6-9].

The results reported here demonstrate several differences between the incorporation of ${ }^{3} \mathrm{H}$-leucine into proinsulin by acomys islets when compared with similar experiments performed on islets of the rat or mouse. The most striking difference concerns the extent of the increase in incorporated ${ }^{3} \mathrm{H}$-leucine into proinsulin in response to glucose. In rat and mouse, ${ }^{3} \mathrm{H}$-leucine incorporation into proinsulin was increased 8-11 fold as the glucose concentration was increased from $2.75 \mathrm{mM}$ to $27.5 \mathrm{mM}$. In the acomys the increase was only 2 fold. At $2.75 \mathrm{mM}$ the absolute amount of ${ }^{3} \mathrm{H}$-leucine incorporated into proinsulin in 
rat and acomys islets was approximately the same. However, the amount of ${ }^{3} \mathrm{H}$-leucine incorporated into total proteins was quite different. In Table 4 for instance it is shown that while rat islets incorporated 328 $\mathrm{dpm}$ and mouse islets, $86 \mathrm{dpm}$, the acomys islets incorporated $1649 \mathrm{dpm}$. If we assume that the intracellular leucine pools were similar in the two species, then proinsulin synthesis would be similar but total protein synthesis five times greater in acomys than the rat. The latter would be in accord with previous morphological evidence from acomys islets [1-3]. In the latter studies it was concluded that acomys islets contained many polyribosomes, a highly structured and well developed endoplasmic reticulum and prominent Golgi complexes all of which are indicative of very active protein synthesis [20]. If on the other hand we assumed that protein synthesis in islets from the two species was the same and that the difference in counts in total protein reflected an endogenous leucine pool in acomys five time less than that of rat, then proinsulin synthesis would be proceeding at a very low rate (one-fifth that of the rat) and the response to high glucose would be slight. Such a very low level of proinsulin synthesis would appear to be imcompatible with the observed normal or slightly elevated plasma insulin in these animals and elevated pancreatic insulin content [6-9]. Thus we tend to favour the opinion that protein synthesis in acomys islets is greater than that of rat or mouse. The reason for this elevated protein synthesis is obscure. One might speculate that with a reduced response to glucose, pro-insulin synthesis under basal (normal) glucose concentrations is set at a somewhat different level than is the situation with other rodents in which high glucose stimulates both release and proinsulin synthesis.

When the rate at which proinsulin synthesis is stimulated by glucose is considered, differences between acomys and the rat were also observed. In the rat islets, with $5.5 \mathrm{mM}$ glucose, two changes in the rate of ${ }^{3} \mathrm{H}$-leucine incorporation were apparent. Thus, between 0-15 min and $15-30 \mathrm{~min}$, the rate of ${ }^{3} \mathrm{H}$-leucine incorporation was doubled. This may be due to the time taken for the stimulus of increased glucose concentration to activate the 'switch-on' for increased proinsulin synthesis, so that the rate increase observed between the first $15 \mathrm{~min}$ after glucose addition and the second 15 min may be artifactual in that it incorporates a time delay in the first period which is not present for the second. No significant difference in ${ }^{3} \mathrm{H}$-leucine incorporation occurred between the periods $15-30 \mathrm{~min}$ and $30-45 \mathrm{~min}$ but a further change in rate was apparent between $30-45$ and 45-60 min. This might be coincidental with the onset of newly stimulated messenger RNA formation [19] and consequent further increase in the rate of proinsu- lin synthesis. For acomys, the results were quite different. A small increase in rate was observed at $15-30$ min relative to $0-15 \mathrm{~min}$ but no change thereon. This would be in accord with the slight stimulatory effect of $5.5 \mathrm{mM}$ glucose in acomys islets. A similar pattern of increase was seen with $27.5 \mathrm{mM}$ glucose which also has only modest effects on proinsulin synthesis in acomys. When rat islets were studied with $27.5 \mathrm{mM}$ glucose in the media the only rate change seen after the first $0-15 \mathrm{~min}$ period was at $15-30 \mathrm{~min}$. This would be consistent with a rapid stimulation of the rate of proinsulin to high levels (9-fold compared with $2.75 \mathrm{mM}$ ) and no significant increase above this by newly formed messenger directed synthesis.

The differences observed between acomys and rat and mouse islets are not thought to be due to changes in the ATP content of the islets in response to glucose because only modest increases in ATP content were observed. Both rat and acomys islets exposed to different glucose concentrations showed increases at 27.5 $\mathrm{mM}$ glucose relative to zero glucose, these being nonsignificant in acomys and just significant in rat $(\mathrm{p}<$ $0.05)$.

In conclusion, the rate of proinsulin synthesis in acomys islets of Langerhans responds to increased glucose concentrations only poorly. The rate of ${ }^{3} \mathrm{H}$-leucine incorporation increased only two-fold when glucose was raised from 2.75 to $27.5 \mathrm{mM}$ in contrast to islets from rats or mice which exhibited large changes. It may be that this decreased sensitivity to glucose is similar in nature to the decreased sensitivity exhibited by the insulin release mechanism of acomys islets. The reasons for the sensitivity defect are obscure. Previous experiments on rat islets have shown that the concentration ranges for glucose stimulation of insulin release and insulin synthesis are different [21], suggesting that different receptor (sensor) mechanisms are involved. The evidence in acomys for decreased sensitivity of both release and synthesis might suggest that there are common features at some point between the reception of glucose and the control mechanisms for synthesis and release of insulin.

\section{References}

1. Pictet, R., Orci, L., Gorlet, A.E., Rouiller, C., Renold, A.E.: Ultrastructural studies of the hyperplastic islets of Langerhans of spiny mice (Acomys cahirinus) before and during the development of hyperglycemia. Diabetologia 3, 188-211 (1967)

2. Junod, A., Letarte, J., Lambert, A. E., Stauffacher, W.: Studies in spiny mice (Acomys cahirinus): Metabolic state and pancreatic insulin release in vitro. Horm. Metab. Res. 1, 45-52 (1969)

3. Stauffacher, W., Orci, L., Amherdt, M., Burr, I. M., Balant, L., Froesch, E.R., Renold, A.E.: Metabolic state, pancreatic insu- 
lin content and $\beta$-cell morphology of normoglycemic spiny mice (Acomys cahirinus): Indications for an impairment of insulin secretion. Diabetologia 6, 330-342 (1970)

4. Cameron, D.P., Stauffacher, W., Orci, L., Amherdt, M., Renold, A.E.: Defective immunoreactive insulin secretion in the Acomys cahirinus. Diabetes 21, 1060-1071 (1972)

5. Cameron, D.P., Stauffacher, W., Amherdt, M., Orci, L., Renold, A.E.: Kinetics of immunoreactive insulin release in obese hyperglycemic laboratory rodents. Endocrinology 92, 257-264 (1973)

6. Gutzeit, A., Rabinovitch, A., Studer, P.P., Trueheart, P.A., Cerasi, E., Renold, A.E.: Decreased intravenous glucose tolerance and low plasma insulin response in spiny mice. Diabetologia 10, 667-670 (1974)

7. Gutzeit, A., Rabinovitch, A., Karakash, C., Stauffacher, W., Renold, A.E., Cerasi, E.: Evidence for decreased sensitivity to glucose of isolated islets from spiny mice (Acomys cahirinus). Diabetologia 10, 661-665 (1974)

8. Rabinovitch, A., Gutzeit, A., Kikuchi, M., Cerasi, E., Renold, A.E.: Defective early phase insulin release in perifused isolated pancreatic islets of spiny mice (Acomys cahirinus). Diabetologia 11, 457-465 (1975)

9. Rabinovitch, A.; Gutzeit, A., Grill, V., Kikuchi, M., Renold, A.E., Cerasi, E.: Defective insulin secretion in the spiny mouse (Acomys cahirinus). Israel J. med. Sci. 11, 730-737 (1975)

10. Cerasi, E., Luft, R.: Plasma insulin responses to glucose infusion in healthy subjects and in diabetes mellitus. Acta endocr. (Kbh.) 55, 278-304 (1967)

11. Cerasi, E., Luft, R., Efendic, S.: Decreased sensitivity of the pancreatic beta cells to glucose in prediabetic and diabetic subjects. A dose-response study. Diabetes 21, 224-234 (1972)

12. Soeldner, J.S., Gleason, R.E., Willians, R.F., Garcia, M.J., Beardwood, D.M., Marble, A.: Diminished serum insulin response to glucose in genetic prediabetic males with normal glucose tolerance. Diabetes 17, 17-26 (1968)

13. Lacy, P.E., Kostianovsky, M.: Method for the isolation of intact islets of Langerhans from the rat pancreas. Diabetes 16, 35-39 (1967)

14. Herbert, V., Lau, K. S., Gottlieb, C. W., Bleicher, S. J.: Coated charcoal immunoassay of insulin. J. clin. Endocr. 25, 1375-1384 (1965)
15. Hunter, W.M., Greenwood, F.C.: Preparation of iodine-131 labelled human growth hormone of high specific activity. Nature (Lond.) 194, 495-496 (1962)

16. Strehler, B.L., Totter, J. R.: Determination of ATP and related compounds: Firefly luminescence and other methods. In: Methods of biochemical analysis (ed. D. Glick), Vol. 1, p. 341. New York: Interscience 1954

17. Wettermark, G., Tegner, L., Brolin, S. E., Borglund, E.: Photokinetic measurement of the ATP and ADP levels in isolated islets of Langerhans. In: Structure and metabolism of pancreatic islets. Werner-Gren Symposium No. 16 (eds. S. Falkmer, B. Hellman, I. B. Täljedal), pp. 275-282. Oxford: Pergamon Press 1970

18. Ashcroft, S.J.H., Chatra, L., Weerasinghe, C., Randle, P.J.: Interrelationship of islet metabolism, adenosine triphosphate content and insulin release. Biochem. J. 132, 223-231 (1973)

19. Permutt, M.A., Kipnis, D.M.: Insulin biosynthesis. I. On the mechanism of glucose stimulation. J. biol. Chem. 247, 1194-1199 (1972)

20. Renold, A.E., Orci, L., Stauffacher, W., Junod, A., Rouiller, C.: Remarks on pancreatic $\beta$-cells in spontaneous and experimental diabetes in small laboratory rodents. In: The structure and metabolism of the pancreatic islets. Werner-Gren symposium No. 16. (eds. S. Falkmer, B. Hellman, I. B. Täljedal), pp. 497-513. Oxford and New York: Pergamon Press 1970

21. Pipeleers, D.G., Marichal, M., Malaisse, W.J.: The stimulussecretion coupling of glucose-induced insulin release XIV. Glucose regulation of insular biosynthetic activity. Endocrinology 93, 1001-1011 (1973)

Received: December 30, 1975, and in revised form: June 21, 1976

Dr. P.A. Trueheart

Dept. of Internal Medicine

Metabolism Division

Barnes and Whol Hospitals

660 South Euclid Avenue

St. Louis, Missouri 63110

USA 